\title{
Effect of prepartum exercise on lying behavior, labor length, and cortisol concentrations
}

\author{
R. A. Black ${ }^{1,2}$ (๑) and P. D. Krawczel ${ }^{1 *}$ (1) \\ ${ }^{1}$ Department of Animal Science, University of Tennessee, Knoxville 37996 \\ ${ }^{2}$ University of California Cooperative Extension, Santa Rosa 95407
}

\section{ABSTRACT}

The objective of this study was to assess the effect of exercise and pasture turnout on lying behavior, labor length, and cortisol concentrations around the time of parturition in dairy cows. Twenty-nine primiparous and 31 multiparous, pregnant, nonlactating Holstein $(\mathrm{n}=$ $58)$ and Jersey $\times$ Holstein cross $(\mathrm{n}=2)$ dairy cows were assigned to control $(\mathrm{n}=20)$, exercise $(\mathrm{n}=20)$, or pasture $(\mathrm{n}=20)$ treatments at dry-off using rolling enrollment. Control cows remained in the dry cow group pen. Exercise cows were removed from the dry cow group pen 5 times per week and walked for $1.4 \pm$ $0.1 \mathrm{~h}$ at $1.88 \pm 0.58 \mathrm{~km} / \mathrm{h}$. Pasture cows were moved to an outdoor paddock 5 times per week for $1.8 \pm 0.3$ $\mathrm{h} / \mathrm{d}$. Cows were housed in deep-bedded sand freestalls in a naturally ventilated, 4-row freestall barn. Cows were moved into maternity pens on the day of projected calving or when cows displayed signs that calving was imminent (restlessness, raised or lifted tail, ruptured amniotic sac, or swollen vulva), and treatments were discontinued. Cameras continuously recorded cows from entry into the pen until farm staff noted a calf, and one observer continuously watched video for two visually observable periods throughout the calving process: time from initial observation of amniotic sac to initial observation of calf's feet, and time from initial observation of calf's feet to full expulsion of calf. Assisted calvings were excluded. Accelerometers were attached to the rear fetlocks of cows $3 \mathrm{~d}$ before dry-off and removed $14 \mathrm{~d}$ postpartum. Activity was summarized by day for the $7 \mathrm{~d}$ before and after delivery time recorded from video observation into lying time (hours per day), lying bout frequency (bouts per day), lying bout duration (minutes per bout), and steps (number per day). Plasma total cortisol concentration was measured on d 0 and 3 postpartum and determined by a radioimmunoassay procedure using a commercially available

Received November 21, 2018

Accepted August 25, 2019.

*Corresponding author: krawczel@utk.edu kit. Data were analyzed using mixed linear model. During calving, time from appearance of the amniotic sac to appearance of the calf's feet was longer for pasture cows compared with control. Control cows engaged in fewer lying bouts and less overall lying time compared with pasture and exercise cows. Cortisol concentrations were higher on the day of calving compared with $3 \mathrm{~d}$ later, regardless of treatment. Understanding the effects of lying alterations around calving and increases in labor period length may allow for physical activity recommendations for late-gestation dairy cows.

Key words: calving, exercise, cortisol, behavior

\section{INTRODUCTION}

Parturition is considered painful in cattle and swine (Mainau and Manteca, 2011) and leads to systematic inflammation in cattle (Turk et al., 2005; Bionaz et al., 2007). Difficulty during calving was rated one of the most painful conditions in cattle by cattle practitioners in the UK (Huxley and Whay, 2006). Problems during calving can cause subsequent reductions in performance (Dematawena and Berger, 1997). Inadequate expulsive forces (Jackson, 2004), feto-pelvic disproportion (Bellows et al., 1971; Johnson et al., 1988), and malpresentation (Meijering, 1984) are the primary reasons for difficult calvings. (For information on disorders of parturition among other species, see Noakes et al., 2001.) Although strategies exist to alter pelvic area (Benyshek and Little, 1982; Morrison et al., 1986) and fetal size among cattle (Grosz and MacNeil, 2001; Kumar et al., 2016; Maschurek et al., 2018), no strategies are currently employed in dairy management to improve uterine expulsive forces. Exercise offers a potential means to address this deficiency in managing dairy cows around the calving period, as exercise is often used in human prepartum care to ameliorate this condition.

Primiparous women who participated in $1 \mathrm{~h}$ of strengthening and toning exercise twice weekly for a minimum of $12 \mathrm{wk}$ had more spontaneous vaginal delivery, required less oxytocin augmentation during delivery, and had shorter first and second stages of 
labor compared with sedentary women (Beckmann and Beckmann, 1990). Exercise during pregnancy in women has been found to promote muscle tone, strength, and endurance, reduce incidence of cesarean section, and lower discomfort at delivery (Wallace et al., 1986; Hall and Kaufmann, 1987; Kulpa et al., 1987). In cattle, prepartum heifers exercised at $5.47 \mathrm{~km} / \mathrm{h}$ for $1.6 \mathrm{~km} / \mathrm{d}$ for 4 wk exhibited improved ease of calving and faster uterine involution by $42 \mathrm{~d}$ postpartum (Lamb et al., 1979). Similarly, cows housed in a freestall barn $4 \mathrm{wk}$ before calving expelled calves more slowly compared with those housed in a deep straw-bedded group pen, which may allow more physical activity (Campler et al., 2015). Therefore, exercise during the prepartum period may improve uterine strength and tone to reduce length of labor in cows.

The addition of exercise may also alter the behavioral response of cattle at parturition. Cow behavior changes as parturition approaches, characterized by reduced lying time, increased lying bout frequency, increased activity, and reduced feed intake (Huzzey et al., 2005; Miedema et al., 2011; Jensen, 2012). These behavioral alterations can be used to monitor the progression and imminence of calving. Housing on pasture throughout the dry period increased the total number of steps taken and lying bout frequency compared with confined cows (Black and Krawczel, 2016). This suggests that providing cows with access to more physical activity during this period may also enhance the behavioral response to calving, improving detection of calving and subsequently improving reproductive efficiency and neonate vitality (Palombi et al., 2013).

Exercise may also ease the calving process by normalizing endocrine signaling. Maternal corticosteroid levels increase 3- to 4-fold during parturition (Horst and Jorgensen, 1982). Under metabolic stress, cortisol levels may increase 5- to 7-fold (Horst and Jorgensen, 1982), inhibiting the normal calving process. Cortisol reduces production of $\mathrm{PGF}_{2 \alpha}$, causing imbalanced concentrations of $\mathrm{PGF}_{2 \alpha}$ and prostacyclins, which has been noted in cows with retained fetal membranes (Horta et al., 1986). Difficult calving can also intensify the stress response (Civelek et al., 2008), potentially causing a similar imbalance and increasing the risk of retained fetal membranes. Women who exercised during pregnancy produced lower concentrations of cortisol at parturition compared with sedentary controls (Varrassi et al., 1989), indicating that exercise may also be a means to reduce stress at calving.

Because the majority of dairy cattle are managed conventionally (i.e., forage delivered to the cow versus cow harvesting the forage in grazing management; $58.8 \%$; USDA, 2016), it is important to understand the implication of this sedentary lifestyle on calving. Physi- cal activity during late gestation has implications to alter the progression of labor and the behavioral and endocrinological response to calving; however, these changes have not been studied in late-gestation dairy cattle. Therefore, the objective of this study was to assess the effect of exercise and pasture turnout on lying behavior, labor length, and cortisol response around the time of parturition in dairy cows. The hypothesis was that added physical activity, such as pasture turnout or a structured exercise regimen, would alter lying behavior around calving, reduce the length of labor, and reduce maternal cortisol concentrations around calving.

\section{MATERIALS AND METHODS}

\section{Animals, Housing, and Management}

Twenty-nine primiparous and 31 multiparous pregnant, nonlactating Holstein $(\mathrm{n}=58)$ and Jersey $\times$ Holstein cross $(\mathrm{n}=2)$ dairy cows were randomly assigned to either control $(n=20)$, exercise $(n=20)$, or pasture $(\mathrm{n}=20)$ treatments at dry-off, using rolling enrollment from January to November 2015. Treatments were balanced by parity $(1.8 \pm 0.9 ; \pm \mathrm{SD})$, projected matureequivalent FCM $(13,831 \pm 2,028 \mathrm{~kg}$ per lactation), and projected calving date. Cows were managed with a $60-\mathrm{d}$ dry period $(58.5 \pm 5.4 \mathrm{~d})$ divided into far-off (from dry-off to 2 wk before parturition) and close-up periods ( 2 wk before projected parturition).

Cows were housed in a naturally ventilated, 4-row head-to-head freestall barn with drive-through feed bunk at the University of Tennessee's Little River Animal and Environmental Unit (Walland, TN). Deepbedded sand freestalls were $2.4 \mathrm{~m}$ long and $1.2 \mathrm{~m}$ wide, with a neck rail $1.2 \mathrm{~m}$ high positioned $1.7 \mathrm{~m}$ from the curb and a PVC tube brisket board $0.6 \mathrm{~m}$ high placed $1.7 \mathrm{~m}$ from the curb. Fresh sand was added once per week, with manure removed from stalls twice daily before milking the lactating herd (0730 and $1730 \mathrm{~h})$. Fans turned on automatically when temperatures rose above $23^{\circ} \mathrm{C}$. Throughout the study period, study cows were housed in pens measuring $12.1 \mathrm{~m}$ wide and 19.4 $\mathrm{m}$ long, enclosing 24 freestalls and 26 headlocks $(0.6 \mathrm{~m}$ wide), and containing 2 waterers, 1 on each end. Study cows were comingled unless the pen was split into faroff and close-up groups, leaving 12 freestalls and 13 headlocks for each group. Cows were maintained below $80 \%$ stocking density, based on headlock and freestall availability.

Cows were fed twice daily at 0730 and 1530 h. Faroff cows were fed a TMR from dry-off to 2 wk before projected parturition, consisting of $4.5 \mathrm{~kg}$ of ryegrass hay, $3.4 \mathrm{~kg}$ of orchardgrass hay, $2.3 \mathrm{~kg}$ of corn silage, and $2.7 \mathrm{~kg}$ of dry cow grain per cow per day. Close-up 
cows were fed a TMR up to parturition, consisting of $3.6 \mathrm{~kg}$ of orchardgrass hay, $1.8 \mathrm{~kg}$ of clover, $11.3 \mathrm{~kg}$ of corn silage, and $3.0 \mathrm{~kg}$ of dry cow grain per cow per day. All cows had ad libitum access to water, except exercise-treatment cows during exercise.

\section{Experimental Treatments}

Before enrollment, all cows were housed in the same freestall barn with no previous experience, with a structured exercise program for the duration of their current lactations. Cows enrolled in the trial were previously provided pasture at 2 different stages of their life cycle; as weaned heifers until they entered the lactating herd and during their previous dry period. All enrolled cows were managed within the same far-off and close-up pens. Cows were enrolled in 1 of 3 treatments (control, exercise, or pasture) on the day of dry-off. Cows assigned to control remained in the pen at all times, except for general management reasons (e.g., cleaning, rebedding stalls) when cows were moved to an adjacent lane for a maximum of $30 \mathrm{~min}$. Cows were permitted to eat, drink, and move around the pen during periods when other treatment groups were exercised or pastured. Cows assigned to exercise were removed from the pen 5 times per week, Monday through Friday, and walked for a targeted $1.5 \mathrm{~h}$ at $3.25 \mathrm{~km} / \mathrm{h}$ beginning at $1200 \mathrm{~h}$, along a path inside the freestall barn (Black et al., 2017a). Cows were walked in a single group using the cows' flight zones and implements (i.e., rattle paddle, long pole, pom-pom) to encourage walking. If a cow stopped walking, pressure was applied to the thigh using a hand ("push") or the tail was gently lifted. Cows were not struck or shocked to encourage movement, as this might have increased stress. No cows refused to move after encouragement. Throughout the project, 5 researchers conducted exercise treatments, with 1 or 2 people exercising cows at a time. Exercise pace was calculated by the total exercise time divided by the distance walked. During periods of high heat load, determined subjectively through cow heat stress behavior (e.g., increased respiration rate, panting), cows were offered water from a 19-L bucket at the point at which the walking path met the entrance to the milking parlor. Cows did not have access to feed during the exercise period.

Cows on pasture were moved into a 2.11-ha pasture (pasture 1) from January to April 2015 and to a 0.42ha pasture (pasture 2) from April to December 20155 times per week, Monday to Friday. Pasture 1 was $330 \mathrm{~m}$ from the barn to the pasture gate, and pasture 2 was 15 $\mathrm{m}$ from the barn to the pasture gate. Pasture 1 had rolling hills and a 0.75-ha wooded area, whereas pasture 2 had a shade structure and trees around one side of the fence line. Both pastures were seeded with orchardgrass and KY-31 fescue, managed by the farm manager for a height of 0.3 to $0.5 \mathrm{~m}$. Cows were put on pasture before staff exercised cows from the exercise treatment group and were returned to the barn afterward. Cows were put on pasture for a target of $1.5 \mathrm{~h}$, excluding travel time to and from the paddock, beginning at $1200 \mathrm{~h}$. Cows on both pastures had ad libitum access to water and grass.

\section{Labor Length and Lying Behavior}

Cows were monitored for signs of calving by farm staff regularly between 0730 and $2100 \mathrm{~h}$ and moved into 1 of 4 individual maternity pens by farm staff on the day of projected calving or when cows displayed signs that calving was imminent (restlessness, raised or lifted tail, water breaking, swollen vulva), and treatments were discontinued. Maternity pens were $4.2 \times$ $4.1 \mathrm{~m}$ and contained a rubber-filled mattress that covered the entire pen floor (ProMat Inc., Woodstock, ON, Canada) with no bedding. Each pen housed only 1 cow at a time; cows in maternity pens had access to water and were fed using a rubber tub twice daily. Gestation length was calculated from breeding date to calving date.

\section{Video Observations}

Video cameras were placed at 6 points around the maternity pens, with 1 camera in front of each of the 4 pens and 1 camera placed at each front corner. Pens were lit using red lights to allow observation of behavior during night calvings. Cameras continuously recorded cows from entry into the pen until farm staff noted a calf. A single unblinded observer viewed all video and noted 2 visually observable periods throughout the calving process (Figure 1), determining the length of each period $(\min )$. The periods were then added together to determine the length of stage II labor (appearance of the amniotic sac to birth). Cows that needed assistance during calving were not included in labor length analyses; however, delivery time for these cows was recorded for inclusion in lying behavior analyses.

\section{Lying Behavior}

Behavior is dynamic during the week preceding and following calving, and changes in management or health status may influence the degree to which cows alter those behaviors and recover (Huzzey et al., 2005; Huzzey et al., 2007; Black and Krawczel, 2016). Accelerometers (IceTag, IceRobotics, Edinburgh, UK) were attached to the rear fetlock of cows $3 \mathrm{~d}$ before 
dry-off and removed $14 \mathrm{~d}$ postpartum. Activity was summarized by day for the $7 \mathrm{~d}$ before and $7 \mathrm{~d}$ after delivery time recorded from video observation. For daily summarization, $\mathrm{d}-1$ indicated the 24 -h period before calving, and d 1 indicated the 24 -h period after calving, with data summarized into lying time (hours per day), lying bout frequency (bouts per day), lying bout duration (minutes per bout), and steps (number per day). All lying bouts under 2 min were removed (Endres and Barberg, 2007).

\section{Cortisol Measurement}

Blood samples were collected from cows on $\mathrm{d} 0$ and 3 postpartum in $6-\mathrm{mL}$ sodium heparin tubes (BD Vacutainer, Becton Dickinson, Franklin Lakes, NJ) from the coccygeal vein while cows were in a palpation chute. Blood was drawn before the health exam, to reduce confounding stress. Blood was drawn once a recently calved cow was moved into a palpation chute or between 0900 and $1100 \mathrm{~h}$ as cows exited the milking parlor, among cows that calved after $1700 \mathrm{~h}$ the previous day. As cows were routinely restrained for blood collection in the palpation chutes during the dry period (Black, 2016), we expected that cows would exhibit some acclimation to this process, reducing the effects of confounding handling stress (Hemsworth et al., 1989). Blood was drawn between 0900 and 1100 $\mathrm{h}$ as cows exited the milking parlor to obtain the d-3 sample. Samples were centrifuged, plasma separated into microcentrifuge tubes, and tubes frozen at $-80^{\circ} \mathrm{C}$. Plasma total cortisol concentration was determined via a radioimmunoassay procedure using a commercially available kit (ImmunChem Cortisol 125 RIA Kit, BP Biomedical, Orangeburg, NY). Samples below detection limits were omitted. Inter- and intra-assay CV for the low control $(7 \mathrm{ng} / \mathrm{mL})$ were $24.5 \%$ and $28.8 \%$, respectively, and $11.7 \%$ and $3.6 \%$, respectively, for the high control $(25 \mathrm{ng} / \mathrm{mL})$.

\section{Statistical Analysis}

A total of 38 calvings and delivery times were recorded $($ control $=10$, exercise $=13$, pasture $=15)$. Calvings not recorded were due to calving within the freestalls or cameras not being set to record when a cow entered the maternity pen $(\mathrm{n}=21)$. One cow had a cesarean section at the University of Tennessee College of Veterinary Medicine Farm Animal Hospital. Of the 38 recorded calvings, 9 were not included within the labor

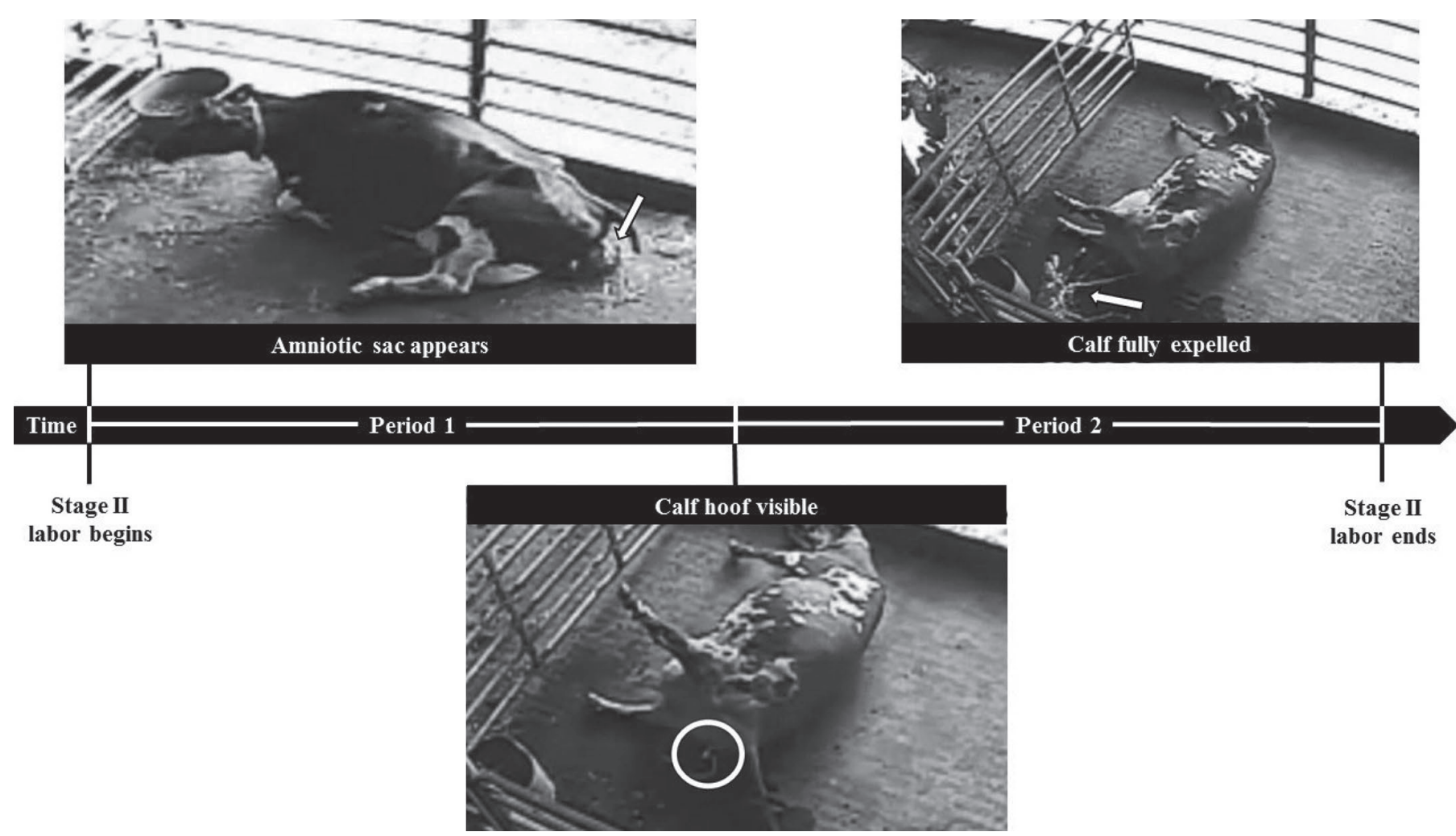

Figure 1. Visually observable periods during stage II labor. Period 1 includes the time from initial observation of the amniotic sac to initial observation of one or both of calf's feet. Period 2 includes time from initial observation of one or both of calf's feet to full expulsion of calf, where both back (or front if breech calving) feet are visible. 
analysis due to assistance during calving (exercise $=2$, pasture $=7$ ). Of the remaining 29 calvings, 19 included the entirety of stage II labor (period 1 and period 2), and 10 only captured period 2 . Therefore, labor analyses used 19 calvings for total stage II labor and period 1 lengths (control $=7$, exercise $=8$, pasture $=4$ ) and 29 cows for period 2 length $($ control $=10$, exercise $=$ 11 , pasture $=8)$. A total of 42 accelerometers correctly functioned throughout the study period $($ control $=14$, exercise $=14$, pasture $=14$ ), with 24 cows having a delivery time recorded (control $=5$, exercise $=8$, pasture $=11$ ) and used for the activity analysis. One cow was excluded from the calving cortisol analyses (pasture $=1$ ) due to a caesarean section at the University of Tennessee College of Veterinary Medicine Farm Animal Hospital and inability to collect blood samples. A total of 24 cortisol samples were omitted from analysis due to undetectable concentrations (day of calving: control $=1$, exercise $=1$, pasture $=2 ; 3 \mathrm{~d}$ following calving: control $=7$, exercise $=6$, pasture $=7$ ).

The experimental and observational unit of this study was the cow. Normality of data was tested using the UNIVARIATE procedure of SAS (SAS 9.4, SAS Inst., Cary, NC). Data were analyzed using a mixed linear model in SAS. Cow within treatment was considered a random variable. Due to the nonsignificant effect of different pastures, pasture 1 and pasture 2 were considered to be one "pasture" treatment, and data were averaged across both pastures. Total stage II labor length was analyzed using treatment (control, exercise, pasture) as the explanatory variable. Length of each labor period was analyzed using treatment, labor period (period 1, period 2), and their interaction as explanatory variables. Treatment, day ( $\mathrm{d}-7$ to 7 , relative to calving), and treatment $x$ day were explanatory variables used to analyze daily lying behavior and activity, with observations repeated by day and an autoregressive covariate structure.

Cortisol data were analyzed using a generalized linear mixed model. Treatment, day (d 0 and 3 relative to calving), and treatment $\times$ day were explanatory variables use to analyze cortisol concentrations. KenwardRoger adjustments were used to generalize degrees of freedom (Padilla and Algina, 2007). The Bonferroni correction was used to compare the least squares means in categorically distributed variables for all statistical tests.

\section{RESULTS}

\section{Descriptive Statistics}

Exercise cows walked for $1.4 \pm 0.1 \mathrm{~h} / \mathrm{d}$ at $1.88 \pm$ $0.58 \mathrm{~km} / \mathrm{h}$ during the treatment period. While exer- cised, exercise group size averaged $( \pm \mathrm{SD}) 3.7 \pm 1.6$ cows, with a minimum of 1 cow and maximum of 8 . Pasture cows spent a mean $( \pm \mathrm{SD})$ of $2.0 \pm 0.3 \mathrm{~h} / \mathrm{d}$ on pasture 1 and $1.7 \pm 0.3 \mathrm{~h} / \mathrm{d}$ on pasture 2 during the treatment period. While pastured, pasture group size averaged $( \pm \mathrm{SD}) 4.0 \pm 1.6$, with a minimum of 1 cow and maximum of 7 . While other cows were exercised or pastured, control group size averaged $( \pm \mathrm{SD}) 3.7 \pm$ 1.2 , within a minimum of 1 cow and maximum of 6 . Exercise, pasture, and control cows took a mean $( \pm \mathrm{SD})$ $2,890.6 \pm 1,085.2,2,117.7 \pm 775.6$, and $1,785.7 \pm 791.8$ steps/d, respectively, during the dry period.

\section{Labor Length}

Treatment did not affect the total length of stage II labor (control $49.0 \pm 17.7 \mathrm{~min}$, exercise $74.1 \pm 16.6 \mathrm{~min}$, pasture $\left.93.9 \pm 23.4 \mathrm{~min} ; F_{1,16}=1.25, P=0.31\right)$. Treatment $\times$ labor period did affect labor period lengths $\left(F_{1,16}=3.71, P=0.047\right)$. Period 1 length was longer for pasture cows $(76.3 \pm 15.5 \mathrm{~min})$ compared with control cows $(21.3 \pm 11.8 \mathrm{~min} ; P=0.01)$, although neither differed from exercise cows $(48.9 \pm 11.0 \mathrm{~min} ; P>0.11)$. No treatments differed in length of period 2 (control: $29.6 \pm 9.8 \mathrm{~min}$, exercise: $23.4 \pm 9.4$, pasture: $18.9 \pm$ $11.0 ; P>0.48)$.

\section{Lying Behavior}

Daily lying time was not affected by treatment $\times$ day $\left(F_{1,294}=1.07, P=0.37\right)$, but control cows tended to lie for less time $(9.8 \pm 0.7 \mathrm{~h} / \mathrm{d})$ compared with exercise $(12.2 \pm 0.6 \mathrm{~h} / \mathrm{d})$ or pasture cows $(11.7 \pm 0.5 \mathrm{~h} / \mathrm{d}$; $\left.F_{1,21}=3.33, P=0.06\right)$ during the $7 \mathrm{~d}$ preceding and following calving. Cows laid down for a shorter time on $\mathrm{d}-1$ compared with $\mathrm{d}-7,-6,-5,1,3,5$, and 7 and a longer time on $\mathrm{d} 1$ compared with $\mathrm{d}-3$ (Figure $\left.2 ; F_{1,294}=4.09, P<0.0001\right)$. Lying bout frequency was not affected by treatment $\times$ day $\left(F_{1,294}=1.07\right.$, $P=0.37$ ) or treatment (control: $10.9 \pm 1.0$ bouts $/ \mathrm{d}$, exercise: $9.1 \pm 0.8$ bouts/d, pasture: $8.8 \pm 0.7$ bouts/d; $\left.F_{1,21}=1.78, P=0.19\right)$. Cows changed posture more frequently on d 1 compared with d -3 or 2 (Figure 3 ; $\left.F_{1,294}=2.38, P<0.01\right)$. Lying bout duration was not affected by treatment $\times$ day $\left(F_{1,294}=0.79, P=0.76\right)$, but control cows had shorter lying bouts $(58.8 \pm 9.4$ min/bout) compared with exercise (90.7 $\pm 7.1 \mathrm{~min} /$ bout $)$ or pasture cows $\left(87.0 \pm 5.7 \mathrm{~min} /\right.$ bout; $F_{1,21}=$ $5.29, P=0.03)$. Cows had shorter lying bouts on $\mathrm{d}-1$ compared with d -7 or -2 (Figure $4 ; F_{1,294}=2.41, P=$ $0.01)$. Daily steps were not affected by treatment $\times$ day $\left(F_{1.294}=0.97, P=0.51\right)$ or treatment (control: $2,189.4$ $\pm 192.8 \mathrm{steps} / \mathrm{d}$, exercise: $2,158.9 \pm 152.4 \mathrm{steps} / \mathrm{d}$, pasture: $2,030.2 \pm 130.0$ steps $\left./ \mathrm{d} ; F_{1,21}=0.37, P=0.70\right)$. 
Cows took more steps on d -1 compared with d 1,6 , or 7 (Figure $5 ; F_{1,294}=2.88, P<0.001$ ).

\section{Cortisol Measurement}

Cortisol concentrations around calving were not affected by treatment $\times$ day $\left(F_{1,49}=2.68, P=0.08\right)$ or treatment (control: $5.41 \pm 1.17 \mathrm{ng} / \mathrm{mL}$, exercise: $5.59 \pm$ $1.15 \mathrm{ng} / \mathrm{mL}$, pasture: $7.34 \pm 1.15 \mathrm{ng} / \mathrm{mL} ; F_{1,51}=0.85$, $P=0.43)$. However, cortisol concentrations were higher on the day of calving $(8.19 \pm 0.83 \mathrm{ng} / \mathrm{mL})$ compared with 3 d later $\left(4.04 \pm 1.01 \mathrm{ng} / \mathrm{mL} ; F_{1,49}=10.39, P<\right.$ $0.01)$.

\section{DISCUSSION}

This is the first study to examine the effects of physical activity on lying behavior, labor length, and cortisol response of late-gestation cows. Compared with control cows, exercise and pasture cows altered their behavior less leading into calving, through increased lying time, and had longer, more frequent lying bouts. However, all cows showed reduced lying time, increased lying bout frequency, reduced lying bout duration, and increased activity preceding calving. Cortisol concentration at and following calving did not differ among treatments but did decrease from calving to $3 \mathrm{~d}$ postpartum.

Behavioral changes occur during all 3 stages of labor, characterized by reduced lying time, increased lying bout frequency, increased activity, and reduced feed intake (Huzzey et al., 2005; Miedema et al., 2011; Jensen, 2012). These changes were observed across all treatments in the current study; however, changes were more pronounced in control cows, particularly through shorter, more frequent lying bouts and a tendency to reduce lying time. Although research has not noted a connection between total standing time and lying bout lengths with difficult calvings, more frequent lying bouts were associated with calving discomfort (Proudfoot et al., 2009), indicating that control cows may have been more uncomfortable compared with exercise and pasture cows during the hours around parturition. However, the small control group sample size $(\mathrm{n}=5)$ warrants caution and further investigation.

The process of calving is typically separated into 3 stages: cervical dilation and uterine contractions (stage

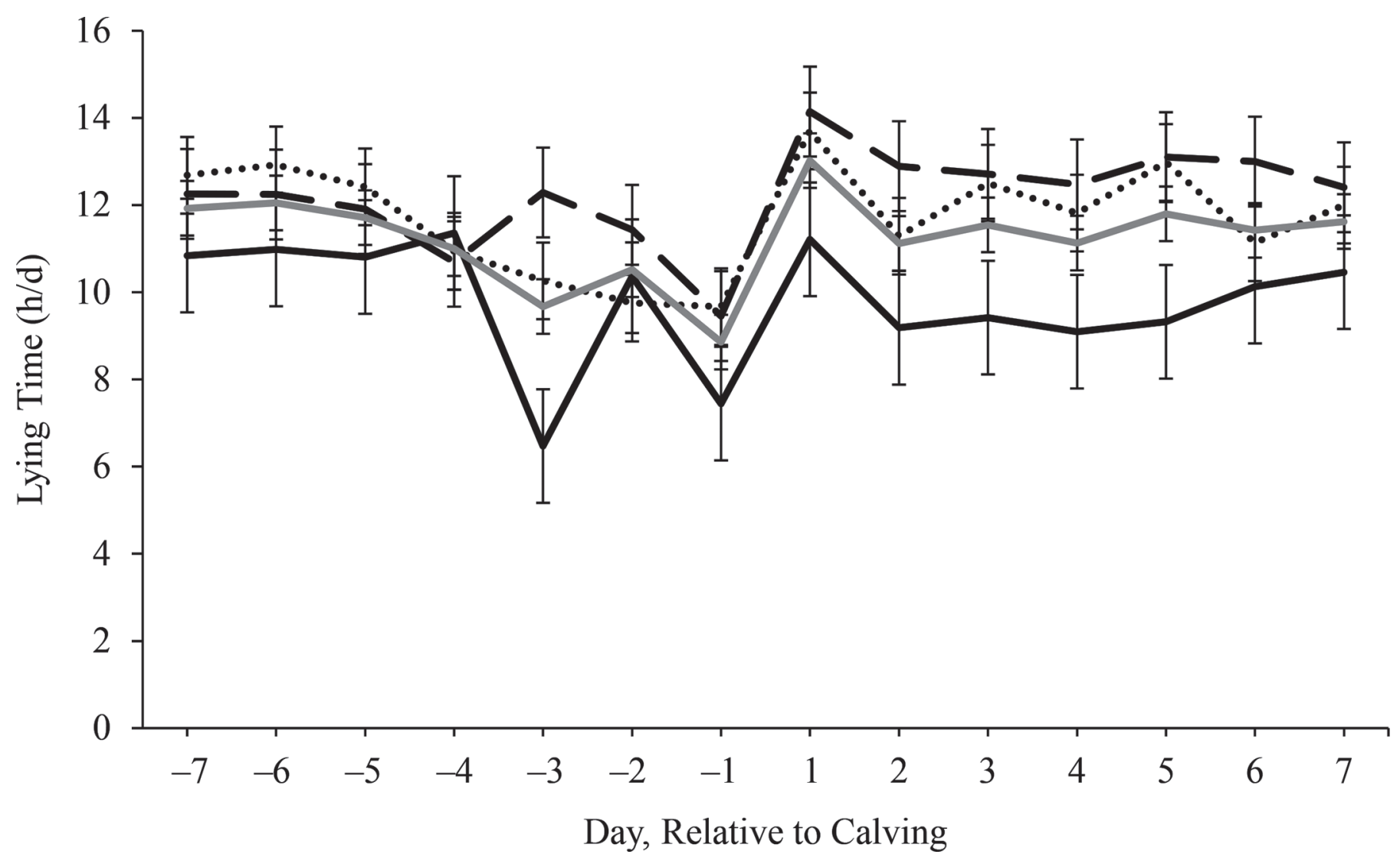

Figure 2. Least squares means $( \pm \mathrm{SE})$ of daily lying time for the $7 \mathrm{~d}$ before and after calving for control $($ solid black line; $\mathrm{n}=5)$, exercise (dashed black line; $\mathrm{n}=8$ ), and pasture (dotted black line; $\mathrm{n}=11$ ) treatments (treatment: $P=0.37$ ) and the average across treatments (solid gray line; day: $P<0.0001)$. 
I), expulsion of the calf (stage II), and expulsion of the fetal membranes (stage III; USDA, 2010). Visual indications of stage I labor (uterine contractions, nestbuilding behavior, tail raising, olfactory ground checks, grooming, vocalization, restlessness, and defecation) can be subjective, may vary among cow and parity, and may extend across stages (Wehrend et al., 2006). However, visual indicators of stage II labor (appearance of amniotic sac, appearance of the calf, and expulsion of the calf) can be objectively determined and do not extend across stages, and periods within this stage can be objectively assessed (USDA, 2010; Schuenemann et al., 2011). Therefore, using the 2 observable periods of stage II labor within this study allowed for a preliminary exploration into how exercise may affect the overall calving process.

Women who completed non-endurance strengthening, stretching, and toning exercises during late gestation experienced a shorter length in stage II labor compared with sedentary controls (Beckmann and Beckmann, 1990). Additionally, cows requiring assistance during calving experienced longer stage II labor, primarily driven by an increase in time from feet appearance to birth (Schuenemann et al., 2011). The current study determined no difference in overall length of stage II labor but an increased time from appearance of the amniotic sac to the appearance of the feet in pasture cows compared with control cows. The difference in period 1 was likely driven by the low animal numbers (control $=7$, exercise $=8$, pasture $=4$ ). However, pasture cows birthed calves with numerically higher birth weights and experienced numerically longer gestation lengths (Black et al., 2017b), which may have affected the calving process. Additionally, because treatments were not balanced on calving ease, pasture cows may have been more prone to longer stage II labor length, necessitating future research to balance treatments on this parameter. This still warrants further investigation into the implications of increased time during period 1 and whether contractions during this period were not sufficient. Beckmann and Beckmann (1990) hypothesized shortened labor period may be related to improved muscle tone, and our exercise regimen for cattle may not have produced similar improvements. Previous work exercising cows used an exercise pace ranging from 3.25 to $4 \mathrm{~km} / \mathrm{h}$ over 5 to $8 \mathrm{~km}$ (Blake et al., 1982; Davidson

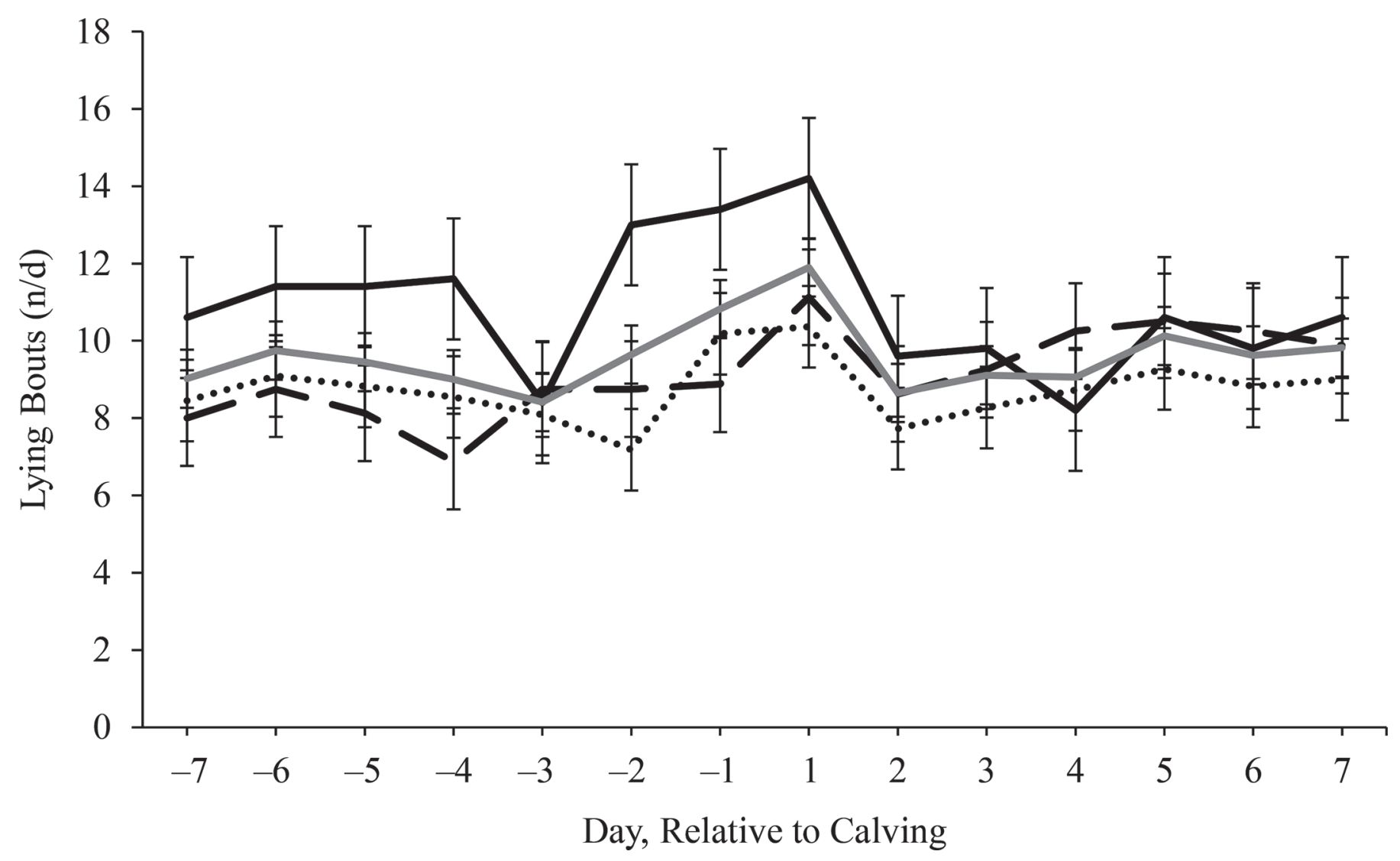

Figure 3. Least squares means $( \pm \mathrm{SE})$ of lying bout frequency for the $7 \mathrm{~d}$ before and after calving for control (solid black line; $\mathrm{n}=5$ ), exercise (dashed black line; $\mathrm{n}=8$ ), and pasture (dotted black line; $\mathrm{n}=11$ ) treatments (treatment: $P=0.39$ ) and the average across treatments (solid gray line; day: $P<0.01)$. 


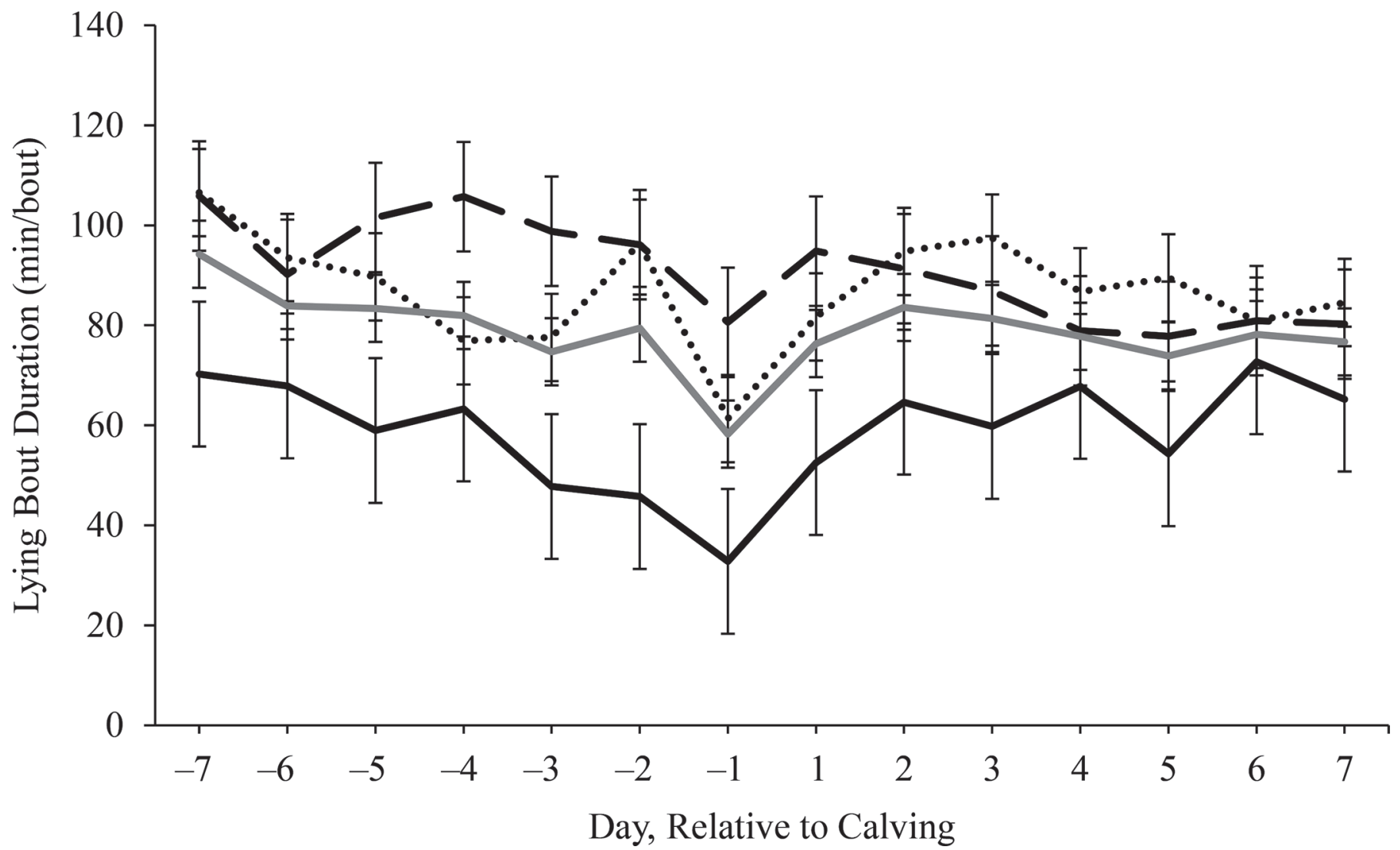

Figure 4. Least squares means $( \pm \mathrm{SE})$ of lying bout duration for the $7 \mathrm{~d}$ before and after calving for control (solid black line; $\mathrm{n}=5)$, exercise (dashed black line; $\mathrm{n}=8$ ), and pasture (dotted black line; $\mathrm{n}=11$ ) treatments (treatment: $P=0.76$ ) and the average across treatments (solid gray line; day: $P=0.01)$.

and Beede, 2009) to attain improved physical fitness, which is greater compared with that experienced by either exercise or pasture cows. Achieving a higher exercise pace or encouraging pasture cows to walk greater distances may produce similar labor outcomes.

A fetal cortisol spike at parturition signals termination of gestation and is coupled with a smaller maternal cortisol spike (Adams and Wagner, 1970; Hoffmann et al., 1973; Hudson et al., 1976). The current study indicates that increased physical activity through exercise or pasture turnout did not affect the concentration of maternal cortisol at parturition. Whereas studies in women noted a reduction in cortisol at birthing with prepartum cycling exercise (Varrassi et al., 1989), the exercise performed in the current study may not have been as intense as cycling. The current study used low-stress handling methods to implement exercise to prevent confounding stress levels, which might have inhibited the necessary level of exercise intensity to induce a change. However, implementing exercise in a more stressful manner might have resulted in chronic stress, which could cause hyper-reactivity of the adrenal cortex to other stressors (Broom, 1988), such as calving, leading to greater levels of postpartum immune dysfunction (Aleri et al., 2016).

Future studies examining the effects of physical activity on lying behavior, labor length, and cortisol responses can assist in understanding the benefits of physical activity in late gestation, as evident in women. Because cows in the current project may not have been exercised intensely enough, implementing an exercise program using equipment to apply exercise in a more structured manner (Anderson et al., 1977) may improve performance outcomes. However, it is important that exercise still be carried out in a low-stress manner, to avoid negative effects on the hypothalamic-pituitaryadrenal axis. Additionally, pasture turnout during the cooler evening hours may encourage activity, as this is when cows are more likely to graze (Walker et al., 2008) and prefer to be on pasture (Legrand et al., 2009).

\section{CONCLUSIONS}

Pasture access during late gestation increased time between the appearance of the amniotic sac and the appearance of the calf's feet compared with confined 


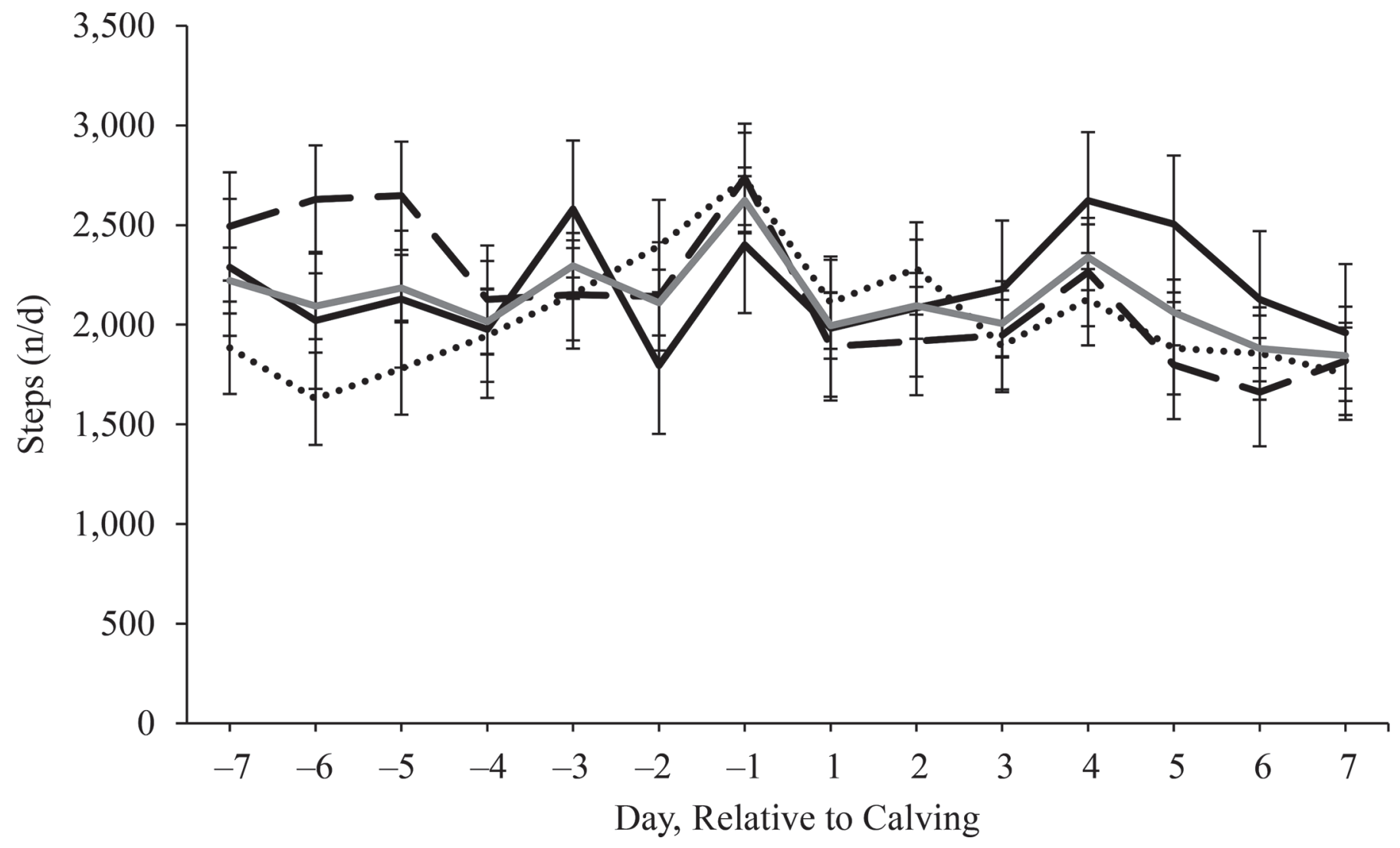

Figure 5. Least squares means $( \pm \mathrm{SE})$ of daily steps for the $7 \mathrm{~d}$ before and after calving for control (solid black line; $\mathrm{n}=5$ ), exercise $($ dashed black line; $\mathrm{n}=8$ ), and pasture (dotted black line; $\mathrm{n}=11$ ) treatments (treatment: $P=0.51$ ) and the average across treatments (solid gray line; day: $P<0.001)$.

cows. However, this may be due to calf size, gestation length, and previous calving difficulty. Understanding how this period within stage II labor affects the calving process warrants additional investigation. All cows exhibited decreased lying time and lying bout duration and increased lying bout frequency and activity. This modification in behavior was pronounced in control cows with shorter, more frequent lying bouts and tendency for reducing daily lying time, potentially indicating more discomfort around calving. Physical activity did not affect cortisol concentrations, but concentrations were higher the day of calving compared with 3 d later. However, small sample sizes and lack of balance for calving difficulty necessitate careful interpretation of study results. Future studies should use more structured methods to exercise cows and turn cows out to farther paddocks to ensure more physical activity outdoors.

\section{REFERENCES}

Adams, W. M., and W. C. Wagner. 1970. The role of corticoids in parturition. Biol. Reprod. 3:223-228.
Aleri, J. W., B. C. Hine, M. F. Pyman, P. D. Mansell, W. J. Wales, B. Mallard, and A. D. Fisher. 2016. Periparturient immunosuppression and strategies to improve dairy cow health during the periparturient period. Res. Vet. Sci. 108:8-17.

Anderson, M. J., R. C. Lamb, C. H. Mickelsen, J. T. Blake, J. D. Olsen, and C. W. Arave. 1977. Facility for exercising dairy cows. J. Dairy Sci. 60:1173-1175.

Beckmann, C. R. B., and C. A. Beckmann. 1990. Effect of a structured antepartum exercise program on pregnancy and labor outcome in primiparas. J. Reprod. Med. 35:704-709.

Bellows, R. A., R. B. Gibson, D. C. Anderson, and R. E. Short. 1971. Precalving body size and pelvic area relationships in Hereford heifers. J. Anim. Sci. 33:455-457.

Benyshek, L. L., and D. E. Little. 1982. Estimates of genetic and phenotypic parameters associated with pelvic area in simmental cattle. J. Anim. Sci. 54:258-263.

Bionaz, M., E. Trevisi, L. Calamari, F. Librandi, A. Ferrari, and G. Bertoni. 2007. Plasma paraoxonase, health, inflammatory conditions, and liver function in transition dairy cows. J. Dairy Sci. 90:1740-1750

Black, R. A., and P. D. Krawczel. 2016. A case study of behaviour and performance of confined or pastured cows during the dry period. Animals (Basel) 6:E41.

Black, R. A. 2016. Alternative approaches to improving the welfare of transition dairy cows and their calves: Use of exercise. $\mathrm{PhD}$ Dissertation. Department of Animal Science, University of Tennessee, Knoxville.

Black, R. A., S. R. van Amstel, and P. D. Krawczel. 2017a. Effect of prepartum exercise, pasture turnout, or total confinement on hoof health. J. Dairy Sci. 100:8338-8346. 
Black, R. A., B. K. Whitlock, and P. D. Krawczel. 2017b. Effect of maternal exercise on calf dry matter intake, weight gain, behavior, and cortisol concentrations at disbudding and weaning. J. Dairy Sci. 100:7390-7400.

Blake, J. T., J. D. Olsen, J. L. Walters, and R. C. Lamb. 1982. Attaining and measuring physical fitness in dairy cattle. J. Dairy Sci. 65:1544-1555.

Broom, D. M. 1988. The scientific assessment of animal welfare. Appl. Anim. Behav. Sci. 20:5-19.

Campler, M., L. Munksgaard, and M. B. Jensen. 2015. The effect of housing on calving behavior and calf vitality in Holstein and Jersey dairy cows. J. Dairy Sci. 98:1797-1804.

Civelek, T., H. A. Celik, G. Avci, and C. C. Cingi. 2008. Effects of dystocia on plasma cortisol and cholesterol levels in Holstein heifers and their newborn calves. Bull. Vet. Inst. Pulawy 52:649-654.

Davidson, J. A., and D. K. Beede. 2009. Exercise training of latepregnant and nonpregnant dairy cows affects physical fitness and acid-base homeostasis. J. Dairy Sci. 92:548-562.

Dematawena, C. M., and P. J. Berger. 1997. Effect of dystocia on yield, fertility, and cow losses and an economic evaluation of dystocia scores for Holsteins. J. Dairy Sci. 80:754-761.

Endres, M. I., and A. E. Barberg. 2007. Behavior of dairy cows in an alternative bedded-pack housing system. J. Dairy Sci. 90:41924200 .

Grosz, M. D., and M. D. MacNeil. 2001. Putative quantitative trait locus affecting birth weight on bovine chromosome 21. J. Anim. Sci. 79:68-72.

Hall, D. C., and D. A. Kaufmann. 1987. Effects of aerobic and strength conditioning on pregnancy outcomes. Am. J. Obstet. Gynecol. 157:1199-1203.

Hemsworth, P. H., J. L. Barnett, A. J. Tilbrook, and C. Hansen. 1989. The effects of handling by humans at calving and during milking on the behaviour and milk cortisol concentrations of primiparous dairy cows. Appl. Anim. Behav. Sci. 22:313-326.

Hoffmann, B., D. Schams, T. Giménez, M. L. Ender, C. Herrmann, and H. Karg. 1973. Changes in progesterone, total oestrogens, corticosteroids, prolactin and LH in bovine peripheral plasma around parturition with special reference to the effect of exogenous corticoids and a prolactin inhibitor respectively. Acta Endocrinol. (Copenh.) 73:385-395.

Horst, R. L., and N. A. Jorgensen. 1982. Elevated plasma cortisol during induced and spontaneous hypocalcemia in ruminants. J. Dairy Sci. 65:2332-2337.

Horta, A. E. M., M. Chassagne, and M. Brochart. 1986. Prostaglandin F2 alpha and prostacyclin imbalance in cows with placental retention: New findings. Ann. Rech. Vet. 17:395-400.

Hudson, S., M. Mullford, W. G. Whittlestone, and E. Payne. 1976. Bovine plasma corticoids during parturition. J. Dairy Sci. 59:744-746.

Huxley, J. N., and H. R. Whay. 2006. Current attitudes of cattle practitioners to pain and the use of analgesics in cattle. Vet. Rec. 159:662-668

Huzzey, J. M., D. M. Veira, D. M. Weary, and M. A. G. von Keyserlingk. 2007. Prepartum behavior and dry matter intake identify dairy cows at risk for metritis. J. Dairy Sci. 90:3220-3233.

Huzzey, J. M., M. A. G. von Keyserlingk, and D. M. Weary. 2005. Changes in feeding, drinking, and standing behavior of dairy cows during the transition period. J. Dairy Sci. 88:2454-2461.

Jackson, P. G. 2004. Handbook of Veterinary Obstetrics. 2nd ed. W. B. Saunders, New York, NY.

Jensen, M. B. 2012. Behaviour around the time of calving in dairy cows. Appl. Anim. Behav. Sci. 139:195-202.

Johnson, S. K., G. H. Deutscher, and A. Parkhurst. 1988. Relationships of pelvic structure, body measurements, pelvic area and calving difficulty. J. Anim. Sci. 66:1081-1088.

Kulpa, P. J., B. M. White, and R. Visscher. 1987. Aerobic exercise in pregnancy. Am. J. Obstet. Gynecol. 156:1395-1403.

Kumar, A., A. Mandal, A. K. Gupta, and P. Ratwan. 2016. Genetic and environmental causes of variation in gestation length of Jersey crossbred cattle. Vet. World 9:351-355.
Lamb, R. C., B. O. Barker, M. J. Anderson, and J. L. Walters. 1979 Effects of forced exercise on two-year-old Holstein heifers. J. Dairy Sci. 62:1791-1797.

Legrand, A. L., M. A. G. von Keyserlingk, and D. M. Weary. 2009 Preference and usage of pasture versus free-stall housing by lactating dairy cattle. J. Dairy Sci. 92:3651-3658.

Mainau, E., and X. Manteca. 2011. Pain and discomfort caused by parturition in cows and sows. Appl. Anim. Behav. Sci. 135:241-251.

Maschurek, N., L. P. Eper, and R. Staufenbiel. 2018. Factors influencing calf birth weight in primiparous and multiparous Holstein Friesian cattle on a dairy farm. Berl. Munch. Tierarztl. Wochenschr. 131:513-521.

Meijering, A. 1984. Dystocia and stillbirth in cattle-A review of causes, relations and implications. Livest. Prod. Sci. 11:143-177.

Miedema, H. M., M. S. Cockram, C. M. Dwyer, and A. I. Macrae. 2011. Changes in the behaviour of dairy cows during the $24 \mathrm{~h}$ before normal calving compared with behaviour during late pregnancy. Appl. Anim. Behav. Sci. 131:8-14.

Morrison, D. G., W. D. Williamson, and P. E. Humes. 1986. Estimates of heritabilities and correlations of traits associated with pelvic area in beef cattle. J. Anim. Sci. 63:432-437.

Noakes, D. E., T. J. Parkinson, and G. C. W. England. 2001. Dystocia and other disorders associated with parturition. Pages 179, 205-217 in Arthur's Veterinary Reproduction and Obstetrics. 8th ed. D. E. Noakes, T. J. Parkinson, G. C. W. England, and G. H. Arthur, ed. W. B. Saunders, Oxford, UK.

Padilla, M. A., and J. Algina. 2007. Type I error rates of the KenwardRoger adjusted degree of freedom $F$-test for a split-plot design with missing values. J. Mod. Appl. Stat. Methods 6:66-80.

Palombi, C., M. Paolucci, G. Stradaioli, M. Corubolo, P. B. Pascolo, and M. Monaci. 2013. Evaluation of remote monitoring of parturition in dairy cattle as a new tool for calving management. BMC Vet. Res. 9:191.

Proudfoot, K. L., J. M. Huzzey, and M. A. G. von Keyserlingk. 2009. The effect of dystocia on the dry matter intake and behavior of Holstein cows. J. Dairy Sci. 92:4937-4944.

Schuenemann, G. M., I. Nieto, S. Bas, K. N. Galvão, and J. Workman. 2011. Assessment of calving progress and reference times for obstetric intervention during dystocia in Holstein dairy cows. J. Dairy Sci. 94:5494-5501.

Turk, R., D. Juretić, D. Gereš, N. Turk, B. Rekić, V. Simeon-Rudolf, M. Robić, and A. Svetina. 2005. Serum paraoxonase activity in dairy cows during pregnancy. Res. Vet. Sci. 79:15-18.

USDA. 2010. Dairy 2007: Heifer calf health and management practices on U.S. dairy operations, 2007. USDA-APHIS-VS CEAH, Fort Collins, CO.

USDA. 2016. Dairy cattle management practices in the United States, Dairy 2014. USDA-APHIS-VS CEAH, Fort Collins, CO.

Varrassi, G., C. Bazzano, and W. Thomas Edwards. 1989. Effects of physical activity on maternal plasma $\beta$-endorphin levels and perception of labor pain. Am. J. Obstet. Gynecol. 160:707-712.

Walker, S. L., R. F. Smith, J. E. Routly, D. N. Jones, M. J. Morris, and H. Dobson. 2008. Lameness, activity time-budgets, and estrus expression in dairy cattle. J. Dairy Sci. 91:4552-4559.

Wallace, A. M., D. B. Boyer, A. Dan, and K. Holm. 1986. Aerobic exercise, maternal self-esteem, and physical discomforts during pregnancy. J. Nurse Midwifery 31:255-262.

Wehrend, A., E. Hofmann, K. Failing, and H. Bostedt. 2006. Behaviour during the first stage of labour in cattle: Influence of parity and dystocia. Appl. Anim. Behav. Sci. 100:164-170.

\section{ORCIDS}

R. A. Black () https://orcid.org/0000-0002-0724-6658

P. D. Krawczel ๑ https://orcid.org/0000-0002-9867-2280 